\title{
Doświadczenie i ewolucja greckiego ideału piękna w koncepcji Pseudo-Dionizego Areopagity. Artysta jako pokorny hymnograf
}

Zanim Pseudo-Dionizy ${ }^{1}$ określił w VI stuleciu Piękno i Dobro ${ }^{2}$ jako przyczynę sprawczą wszelkiego bytu i stawania się, harmonii, porządku i doskonałości, wizja piękna, szczególnie piękna uwznioślonego, uduchowionego, znajdowała się w orbicie zainteresowań klasycznej filozofii. Platon, opisując pragnienie osiagnięcia przez miłość tego, co piękne, wskazuje hierarchię Piękna: piękno cielesne, piękno ukryte w czynach i prawach, piękno w dążeniu do prawdy, która odsłania piękno samo w sobie. Jest to piękno niezmienne i wieczne:

wszystkie inne przedmioty piękne uczestniczą w nim w ten sposób, że podczas gdy same powstają i giną, ono ani się pełniejszym nie staje, ani uboższym, ani go żadna w ogóle zmiana nie dotyka³

1 Pseudo-Dionizy Areopagita, anonimowy pisarz chrześcijański, żyjący na przełomie V/VI w. n.e. w środowisku antiocheńskim. Chciał on, jak podaje Franciszek Drączkowski, uchodzić za Dionizego Ateńczyka, nawróconego na Aeropagu przez św. Pawła (Dz 17, 34); zob. F. Drączkowski, Patrologia, Pelplin-Lublin 1999, s. 415.

2 Dobro - jedno z podstawowych pojęć w kategoriach etycznych. Jest utożsamiane z pojęciem bytu. W moralności określa zgodność z jej normami: czynów i zachowań człowieka. Dla Arystotelesa dobro jest celem wszelkiego dążenia; zob. Arystoteles, Etyka nikomachejska, tłum. D. Gromska, Warszawa 1956, s. 3. O naturze dobra Pseudo-Dionizy pisze: „Na pierwszym miejscu, co wydaje się rzeczą słuszną, zajmijmy się wyjaśnieniem imienia oznaczającego «dobro», które wyraża w najdoskonalszy sposób całość boskiego wylewania się - zwracając się najpierw do Trójcy, przyczyny wszelkiego dobra, wyższej jednak nad dobro [...]. To do niej przede wszystkim winniśmy wznieść nasze modlitwy, jako do zasady dobra"; Pseudo-Dionizy Areopagita, Imiona Boskie, III, 1, [w:] Pseudo-Dionizy Areopagita, Pisma teologiczne. Imiona boskie. Listy, tłum. M. Dzielska, Kraków 1997 , s. 72.

3 Platon, Uczta, XXVIII A - XXIX B, tłum. W. Witwicki, Kęty 2002, s. 76-77. 
Dla Plotyna piękno rzeczy istnieje o tyle, o ile mają one swój udział w idei. Brzydkie jest to wszystko, co bezkształtne i co pozostaje poza boskim Rozumem. Wszelkie rzeczy, które złożone są z wielości, wymagają uporządkowania, ukształtowania według celu, któremu mają służyć. Tę rolę spełnia idea, która w swej naturze jest jednością ${ }^{4}$. Prawdziwe Piękno widzi jednak Plotyn w dziedzinach pozazmysłowych, postrzeganych przez duszę. Do nich wznieść się mogą jedynie

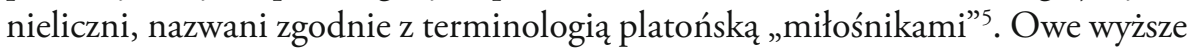
rejony piękna to cnoty: powściągliwości, męstwa i skromności. Pierwsza unika rozkoszy cielesnych, druga nie lęka się śmierci, a tym samym oddzielenia duszy od ciała. Mądrość pozwala na uniesienie duszy wzwyż, przez co staje się ona umysłową, niecielesną ideą i wzbiera pięknością. Na samym szczycie emanuje światło boskiego Rozumu - arcypiękno i najwyższe dobro samo w sobie - które dając wszystko, nie bierze i nie ujmuje sobie niczego ${ }^{6}$. Oto Absolut, Jedno, Bóg, obdarowujący dusze swoich miłośników emanującym pięknem. To Piękno, wprost z duszy, przechodzi również na czyny i uprawiane zajęcia, w tym przede wszystkim sztukę, traktowaną jako narzędzie ukazywania idei, odsłaniającą istotę rzeczy. Inaczej niż w przypadku Platona, który w teorii mimesis nie widział możliwości ukazywania prawdy poprzez sztukę, Plotyn dokonuje zasadniczego zwrotu - pozwala artyście ukazać odblask boskiego Piękna:

Jeżeli zaś ktoś odmawia sztukom uznania, ponieważ tworzą, naśladując naturę, to, po pierwsze, trzeba stwierdzić, że także dzieła natury są naśladownictwem innych wzorów. Trzeba następnie wiedzieć, że sztuki nie naśladują po prostu widzialnego świata, lecz sięgają do wątków, z których się wyłania owa natura, i że wreszcie tworzą wiele same z siebie, albowiem, jeżeli czemuś czegoś nie dostaje, to uzupełniają te braki, gdyż są w posiadaniu piękna ${ }^{7}$.

Według Plotyna artysta, który tworzy, zwraca się do pierwszej, naturalnej mądrości, która i jego samego stworzyła. Nie jest ona niedoskonałą, wymagającą zespolenia wielością, ale czymś jednym, prawdziwą substancją, która jednocześnie jest prawdziwą mądrością. Źródłem wszelkiej mądrości są wizerunki przedwieczne - idee, jako wzór świata, który będąc początkiem oraz końcem, jest wszystkim od razu. Udział w odwzorowywaniu piękna wiecznego jest możliwy, bo człowiek,

4 Zob. Plotyn, Enneady I, 6, przeł. A. Krokiewicz, Warszawa 2000, s. 132.

5 Por. Platon, Fajdros, 248 D, tłum. W. Witwicki, Kęty 2002 Kęty 2002.

6 Plotyn, Enneady I, 6, dz. cyt., s. 134-138.

7 Plotyn, Enneady V, 8, dz. cyt. s. 569. 
chociaż stworzony ze zmieszanych substancji, posiada odblask tych wiecznych idei, ku którym może się zwracać, jeśli tylko dane mu będzie ujrzeć ich piękno ${ }^{8}$.

W takim świetle teorii mimetycznej sztuka nie ogranicza się do naśladownictwa rzeczy przedstawionej, jak chciał Platon, ale sięga do różnych jej aspektów, do rdzenia, idei, i tym sposobem kreuje prawdziwie metafizyczne piękno' . Gruntowną analizę problemu wartości poznawczej sztuki odnajdujemy u XX-wiecznego badacza, Hansa-Georga Gadamera. Stwierdza on, iż wytwory sztuki w relacji mimetycznej nie są jedynie odwzorowaniem, nie ograniczają się tylko do zaistnienia czegoś zaprezentowanego, lecz że istnienie to jest adekwatne, jest rozpoznaniem istoty. W tym sensie naśladowanie pełni tu rolę poznawczą, i dopóki uznaje się poznanie prawdy za poznanie istoty, to sztuka może pełnić swoją rolę w przekonujący sposób ${ }^{10}$.

W eseju na temat dialektyki Plotyn ukazuje możliwości odkrycia boskiego Piękna, wynikającego z dobra i będącego jednocześnie dobrem i prapoczątkiem. Ustala hierarchię tych, którzy ze względu na swoje predyspozycje mogą odbyć tę drogę wzwyż. U stóp tej drabiny stoi muzyk, który będąc istotą wrażliwą i pełną trwożnego zachwytu, jest szczególnie predestynowany do wyjścia poza świat zmysłów. Sam z siebie uciekając przed brakiem harmonii i jedności w melodiach i rytmach, poszukuje w tej materii doskonałości. Nie jest jednak w pełni świadomy tego, że piękno, którego w niej doznaje i za którym podąża, jest pięknem cząstkowym, niedoskonałym i że jego prawdziwe źródło tkwi w bytach wiecznych i harmonii umysłowej. Dlatego należy wskazać mu świetlane orędzie filozofii, aby tą drogą umiał odkryć w sobie skarby, które posiada. Piękno ziemskie ma tu swoją analogię do wartości składników duszy ludzkiej wobec mieszanki duszy świata ${ }^{11}$, o której pisze Platon w Timajosie - jest drugo- i trzeciorzędne.

Stojącego na wyższym szczeblu miłośnika cechuje pewna pamięć piękna. Miłośnik doznaje nad nim zachwytu, ale nie potrafi oddzielić piękna samego w sobie od jego poszczególnych przejawów. Trwożny zachwyt miłośnika należy ukierunkować na świadomość piękna jako bytu różnego od ciał, a zarazem jego aktualizacji we wszystkim, co ożywione i nieożywione, w zajęciach i prawach, w sztuce, w wiedzy, a wreszcie we wszelkich rodzajach cnoty. Po zmysłowym świecie nie błądzi jedynie filozof, w którego przerodzić mogą się zarówno muzyk, jak i miłośnik. Filozof jest już oswojony z bytem niecielesnym i Plotyn pragnie go jedynie

8 Zob, Plotyn, Enneady V, 8, dz. cyt. s. 574-577.

9 Zob. W. Stróżewski, Wokót piękna, Kraków 2002, s. 170.

${ }^{10}$ Zob. H. G. Gadamer, Prawda i metoda. Zarys hermeneutyki filozoficznej, tłum. B. Baran, Kraków 1993, s. 131-133.

${ }^{11}$ Por. Platon, Timajos, 41 D, tłum. W. Witwicki, Kęty 2002, s 39. 
doskonalić w pojęciowym i słownym określaniu każdej z rzeczy tak, by uczynić go dialektykiem i osadzić na polu prawdy, gdzie będzie karmił swoją duszę ${ }^{12}$. Powyższe, hierarchiczne zestawienie stopni: muzyk, miłośnik, filozof, Plotyn wydaje się wynosić z lektury Platona, tj. mowy Sokratesa w Fedonie, w której filozofia jawi się jako największa służba Muzom ${ }^{13}$.

Dla niezwykle kreatywnego spadkobiercy teorii Plotyna - Pseudo-Dionizego Areopagity - piękno, jak pisze Władysław Stróżewskii ${ }^{14}$, stało się wartością o randze symbolu, będącego w mocy wyrazić jedno z tajemniczych imion boskich:

A więc nazywamy pięknym to, co uczestniczy w pięknie, gdy tymczasem piękno uczestniczy w czyniącej piękno przyczynie wszystkiego, co piękne $e^{15}$.

Wszechświat, jaki Pseudo-Dionizy opisuje w Hierarchii niebiańskiej oraz Hierarchii kościelnej, to świat świętego porządku i boskowładczej piękności. $\mathrm{Na}$ samym szczycie jest Bóg w Trójcy Osób. Poniżej boskie opatrzności, hierarchie aniołów, ludzie, wreszcie cały materialny kosmos. Jest to świat poznawalny intelektualnie, w którym wszystko pochodzi od Boga i do Boga powraca ${ }^{16}$. Pseudo-Dionizy przejmuje tu neoplatońską teorię emanacji, którą Proklos, jeden z ostatnich neoplatoników, przedstawia w swoich Elementach teologii. Zasady emanacji, trwania i powrotu ujmuje następująco: „wszelka emanacja dokonuje się przez podobieństwo bytów wtórnych wobec pierwotnych”. „Wszystko to, co jest stwarzane bezpośrednio z czegoś, zarówno trwa w tym, co je stwarza, jak też się z niego wylewa”. „Wszystko, co emanuje z czegoś, swoją substancją zwraca się na powrót ku temu, od czego emanuje. „Wszelki zwrot dokonuje się przez podobieństwo

12 Zob. Plotyn, Enneady I, 3, dz. cyt. s. 107-111.

${ }^{13}$ Por. Platon, Fedon, 61 A, tłum. W. Witwicki, Kęty 1999, s. 23.

${ }_{14}$ Zob. W. Stróżewski, Wokót piękna, dz. cyt., s. 170.

${ }^{15}$ Pseudo-Dionizy Areopagita, Imiona Boskie IV, 7, [w:] Pseudo-Dionizy Areopagita, Pisma teologiczne, tłum. M. Dzielska, Kraków 2005, s. 250.

${ }^{16}$ Zob. Pseudo-Dionizy Areopagita, Hierarchia niebiańska VII, 4, X, 1-3, XIII, 3 [w:] Pseudo-Dionizy Areopagita, Pisma teologiczne II, tłum. M. Dzielska, Kraków 1999, s. 77, 88-89, 94-97. Wartość obydwu dzieł Pseudo-Dionizego docenił Kościół, wskazując na jego myśli w kanonie 2. Soboru Nicejskiego II: „Albowiem, jak stwierdza wielki Dionizy - istotą naszej hierarchii są zasady przekazane przez Boga, to znaczy prawdziwa znajomość świętych Pism”; Dokumenty Soborów Powszechnych, t. I, Sobór Nicejski II (787), oprac. A. Baron, H. Pietras, Kraków 2007, s. 347; por. Pseudo-Dionizy Areopagita, Hierarchia niebiańska, I, 4, dz. cyt., s. 49. 
tych, które się zwracają, do tego, ku czemu się zwracają"17. Według Proklosa podobieństwo wiąże ze sobą wszystko tak, jak niepodobieństwo dzieli i rozłącza. Skoro zatem zwrot stanowi wspólnotę i powiązanie, to wszelka wspólnota i każde powiązanie są wynikiem podobieństwa. $\mathrm{Z}$ tego wynika, iż wszelki zwrot może dokonywać się dzięki podobieństwu ${ }^{18}$.

Dla Pseudo-Dionizego Piękno to atrybut Boga-Absolutu. Jest tożsame z Dobrem, jest jednocześnie Pięknem-i-Dobrem, stanowiąc przyczynę wszystkiego, co w świecie nosi odblask piękna i dobra, przyczynę bytu i stawania się, wiedzy i myśli. Przypisując piękno Stwórcy, Pseudo-Dionizy odbiera je światu. W ten sposób do estetyki chrześcijańskiej wkraczają, jak pisze Władysław Tatarkiewicz, najbardziej abstrakcyjne, a zarazem transcendentne sformułowania piękna ${ }^{19}$. Mówiąc o Bogu, pisze o „prapięknie”, „wszechpiękności”, „nadpiękności”, pięknie „nadsubstancjalnym”. I chociaż świat nie dysponuje pięknem własnym, to każda ziemska materia zawiera echa jego emanacji. W koncepcji emanacyjnej piękno absolutne promieniuje na wzór światła.

To, co piękne nadsubstancjalnie, nazywa się pięknem, ponieważ samo z siebie, na miarę właściwą każdemu, rozdziela wszystkim bytom piękno, jest przyczyną harmonii i świetności wszystkiego i, tak jak światło, obdziela wszystko rodzącymi piękno darami swojej promieniejącej jasności, wzywa wszystko do siebie - stąd właśnie nazywa się pięknem - i wszystko gromadzi w sobie ${ }^{20}$.

${ }^{17}$ Proklos, Elementy teologii, 29, 30, 31,32, tłum. R. Sawa, Warszawa 2002, s. 46-48. W podobny sposób tysiąc lat później udowadnia istnienie Boga św. Tomasz z Akwinu: „Cokolwiek jest poruszane, musi otrzymać ruch od kogoś innego, a jeśli i ten, kto w ruch wprawia, sam jest poruszany, to i on musi otrzymać ruch od kogoś innego; ów zaś jeszcze od innego. Nie można zaś tu iść w nieskończoność, bo w ten sposób nie będzie pierwszego poruszyciela, a co za tym idzie i drugiego, i dalszego, i w ogóle żadnego, gdyż motory podrzędne czy pośrednie o tyle w ruch wprawiają, o ile same są w ruch wprawiane przez pierwszego poruszyciela. [...] Ostatecznie więc w rozumieniu naszym musimy dojść do jakiegoś pierwszego poruszyciela, który już przez nikogo nie jest w ruch wprawiany, i właśnie, w mniemaniu wszystkich, jest nim Bóg; św. Tomasz, Czy Bóg istnieje, [w:] św. Tomasz, Suma teologiczna, I, II, art. 3, tłum. o. P. Bełch, Londyn 1960, s. 48.

${ }^{18}$ Proklos, Elementy teologii, 32, dz. cyt., s. 48.

19 Zob. W. Tatarkiewicz, Historia estetyki, t. 2, Warszawa 2009, s. 33-35.

${ }^{20}$ Pseudo-Dionizy Areopagita, Imiona Boskie, IV, 7, dz. cyt., s. 250. Pseudo-Dionizy w wielu miejscach swej twórczości określał piękno jako blask czy światło (claritas, lumen). W przytoczonym fragmencie połączył go też z greckim odpowiednikiem piękna jako harmonii, proporcji (consonantia) tworząc formułę: consonantia et claritas. M. Dzielska tłumaczy ją jako „harmonię i świetność”, natomiast W. Tatarkiewicz (Historia estetyki, Warszawa 2009, 
To porównanie sprawiło, że pojęcie światła, blasku (claritas) jako piękna weszło na stałe do kanonu średniowiecznej estetyki ${ }^{21}$. Według Dionizego piękno to źródło i zarazem cel wszelkiego bytu. Dążenie do niego to dążenie do prawdy i dobra. Pseudo-Dionizy nie był jednak ani pierwszym, ani jedynym, który przyczynę wszelkiego piękna widział w Bogu. Wczesnochrześcijański teolog-apologeta, ojciec Kościoła, Atanazy Wielki, pisał:

stworzenie, przez porządek i harmonię, jak napis władcę swego i twórcę wskazuje i ogłasza. Albowiem Bóg, dobrym będąc i przyjaznym dla ludzi [...], skoro jednak niewidzialny i nieogarniony jest z natury, bytuje ponad wszelką istotą stworzoną [...], tak stworzenie uporządkował [...] swoim Słowem, żeby, skoro jest niewidzialny z natury, z dzieł mógł być przez ludzi poznany. $Z$ dzieł bowiem często artysta jest poznawany, mimo, że się go nie widzi ${ }^{22}$.

Podobnie Bazyli Wielki twierdził, iż Bóg, który jest twórcą wielkich dzieł, daje we wszystkim zrozumienie swej prawdy po to, aby od rzeczy widzialnych można było dojść poprzez rozum do tego, co niewidzialne, i aby wielkość i piękno stworzeń dały właściwe wyobrażenie o Stwórcy ${ }^{23}$.

Hierarchia, jaką w swoim opisie kreśli Pseudo-Dionizy, jest porządkiem, wiedzą i aktywnością. Tę aktywność definiuje cel, do którego zmierza cała hierarchia - upodabnianie się do Boga i zjednoczenie z Nim. Wszystkie intelekty, anielskie i ziemskie, powinny naśladować Boga na tyle, na ile jest to dla nich możliwe ${ }^{24}$. W swojej myśli Pseudo-Dionizy wychodzi z założenia, iż żadna ziemska rzeczywistość, żaden opis słowny czy też angażujący wszelkiego rodzaju sztuki nie są w stanie wysłowić, a tym samym oddać wprost rzeczywistości boskiej. Skoro zatem nic, co ziemskie, nie może oddać tego, czym Ona jest, odpowiedniejsze wydaje się Pseudo-Dionizemu zastosowanie zasady negacji, a więc artykułowania twierdzeń na temat tego, czym ta rzeczywistość nie jest. Nie istnieje ona bowiem tak, jak inne byty ziemskie, jej nadsubstancjalności

s. 39), podążając, jak się wydaje, za łacińskim tłumaczeniem św. Tomasza, pisze o „proporcji i blasku"; Por. św. Tomasz, In librum Beati Dionysii De divinis nominibus expositio, lectio 5, ed. C. Pera, P. Caramello, C. Mazzantini, Taurini 1950.

${ }^{21}$ Zob. W. Tatarkiewicz, Historia estetyki, dz. cyt. s 36.

22 Atanazy Wielki, Przeciw poganom, 34-35, przeł. M. Wojciechowski, [w:] Pisma starochrześcijańskich pisarzy, t. 62, Warszawa 2000, s. 60

${ }^{23}$ Zob. Bazyli Wielki, Homilia na Hexaemeron, III, 10, przeł. M. Michalski, [w:] Antologie literatury patrystycznej, t. II, Warszawa 1975, s. 65.

${ }^{24}$ Pseudo-Dionizy Areopagita, Hierarchia niebiańska III, 1, dz. cyt., s. 59. 
nie da się pojąć intelektem ani wyrazić żadnym słowem. Pozostaje więc mierzyć się z rzeczami boskimi za pomocą niepodobnych do nich symboli. Im bardziej pospolite są owe symbole, tym dobitniej ukazują przepaść między tym, co ponadświatowe, a tym, co należy do rzeczywistości materialnej. Na te właśnie twierdzenia Pseudo-Dionizego powoła się w przyszłości św. Tomasz z Akwinu, odpowiadając w artykule 9 Sumy teologicznej na pytanie, „czy Pismo Święte powinno używać przenośni?”25.

$\mathrm{Z}$ drugiej strony według Pseudo-Dionizego każdy byt, ponieważ pochodzi od Boga, partycypuje w pięknie, dlatego może stać się źródłem najpiękniejszych kontemplacji. Genezy tej myśli możemy doszukać się w słowach św. Pawła, w jego Liście do Rzymian:

Albowiem od stworzenia świata niewidzialne Jego przymioty - wiekuista Jego potęga oraz bóstwo - stają się widzialne dla umysłu przez Jego dzieła $(\mathrm{Rz} 1,20)$.

Wykształcone przez filozofię neoplatońską owe trzy stopnie inicjacji, prowadzące do osiągnięcia najwyższego pułapu - Królestwa Rozumu - Pseudo-Dionizy przekształca w koncepcję hierarchii niebiańskiej i odpowiadającą jej w ziemskim wymiarze koncepcję hierarchii kościelnej. Wspólnie tworzą one drogę do poznania boskich Prawd. Najwyższe substancje odbierają dopuszczalną dla nich miarą naukę o cudach bożych drogą iluminacji płynącą z łona samej Boskiej Zwierzchności i dalej przekazują ją w dół niższym hierarchiom, by i one mogły otwierać się na wysławianie i przyjęcie Boga, stosownie do swoich predyspozycji. W ten właśnie sposób, stwierdza Pseudo-Dionizy, teksty Pisma przekazały ludziom hymny śpiewane przez Anioły najwyższej hierarchii, w któ-

25 „Bóg zaopatruje potrzeby wszystkich stosownie do ich natury; otóż w naturze człowieka leży to, że wznosi się do tego, co zmysły postrzegają, ku temu, co myślą poznawalne. [...] Zdaniem Dionizego [pisze św. Tomasz, przyp. G. M.] bardziej zgodne z duchem Pisma św. jest uzmysłowienie spraw Bożych za pomocą podobieństw lichych ciał niż ciał szlachetnych, a to z trzech powodów: Pierwsze, bo dzięki temu człowiek łatwiej uniknie błędu; jasno bowiem widzi, że nie mówią o Bogu we właściwym sensie; [...], drugie, bo ten właśnie sposób bardziej odpowiada takiej znajomości Boga, jaka w obecnym życiu jest dla nas dostępna; ukazuje nam bowiem raczej to, czym Bóg nie jest, niż czym jest; dlatego też podobieństwa tych rzeczy, które w hierarchii bytu dalej stoją od Boga, rodzą w nas prawdziwsze i jaskrawsze przekonanie, że Bóg jest ponad tym, co o Nim mówimy lub myślimy; trzecie, bo tego pokroju figury chronią sprawy Boże przed niegodziwością ludzką"; św. Tomasz, Czy Pismo Święte winno używać przenośni, [w:] św. Tomasz, Suma teologiczna, I, 1, art. 9, dz. cyt., s. $40-41$. 
rych ukazana została cała wielkość ich niezwykłej światłości. Hymny i kantyki śpiewane przez Kościół są więc odbiciem hymnów pochodzących z hierarchii niebiańskiej. To one, przepełnione najświętszą prawdą, przygotowują człowieka do sprawowania obrzędów, zestrajają go zarówno z boską rzeczywistością, jak też z drugim człowiekiem na kształt jednobrzmiącego chóru świętych. W takim śpiewie przejawia się jednoczące i jedyne natchnienie, wzbudzone przez Ducha Boskiej Zwierzchności ${ }^{26}$.

Na podstawie powyższego można ujrzeć ewolucję kreślenia wizerunku człowieka pomiędzy filozofią Plotyna a teologią Pseudo-Dionizego. Ten pierwszy przedstawiał muzyka jako istotę wrażliwą i emocjonalną, która łatwo ulegając wzruszeniu, podąża za każdym wizerunkiem piękna. Kiedy zostanie odpowiednio poprowadzona, może ujrzeć nie poszczególne harmonie i zawarte w nich piękno, ale piękno w ogóle, piękno umysłowe, będące samą ideą Piękna. W ujęciu Pseudo-Dionizego piękno jest atrybutem boskim. Muzyk jest tu odbiorcą i przekazicielem piękna zawartego w wiecznych, niebiańskich hymnach. Jego wiara sprawia, że staje się bożym narzędziem, pokornym hymnografem po to, by hymny te mogły być słyszalne w szeregach hierarchii kościelnej. Jest to możliwe, ponieważ on sam jest zamysłem i dziełem Bożym. Chociaż jego twórczość stanowi jedynie echo niebiańskich hymnów to, naznaczona Bożym tchnieniem, jest w stanie wznieść się na wyżyny i ukazać źródło tego piękna.

Jak się więc okazuje, można przedstawiać substancje niebiańskie za pomocą tych niedoskonałych form [...], ponieważ i sama materia zawdzięcza swoją egzystencję Temu, który jest prawdziwie pięknem i zachowuje we wszystkich swoich ziemskich stworzeniach pewne znamiona intelektualnej nadobności. A przecież od tych znamion można się już wznieść na powrót do niematerialnych archetypów ${ }^{27}$.

Powyższy cytat również wyraźnie koresponduje z twierdzeniami zawartymi w Elementach teologii. W tezie 7 (O Jednym) Proklos stwierdza iż, „wszystko to, co tworzy coś innego, jest silniejsze od natury wytworzonego"28. Teza 21 (O intelek-

${ }^{26}$ Pseudo-Dionizy Areopagita, Hierarchia kościelna, III, 5, [w:] Pseudo-Dionizy Areopagita, Pisma teologiczne II, dz. cyt., s. 141.

${ }^{27}$ Pseudo-Dionizy Areopagita, Hierarchia niebiańska, II, 4, dz. cyt., s. 56.

${ }^{28}$ Proklos, Elementy teologii, 7, dz. cyt., s. 31. Pierwowzór tej tezy, a także echa wywodów Platona (Prawa, X) zdradza myśl Augustyna, który w dziele O nieśmiertelności duszy pisze: „Istnieje pewnego rodzaju siła we wszystkim, co jest stałe. Wszystko, co jest stałe, jest niezmien- 
cie) mówi: „wszelki porządek, wywodząc się z jedni, emanuje w wielość jednorodną z tą samą jednią, a wielość w każdym porządku wznosi się ku jednej jedni”29. Źródeł tych tez można doszukać się w twórczości samego Platona, dla którego prapoczątkiem wszelkiego bytu i ruchu (przemiany) była dusza:

Jeżeli natomiast to, co samo siebie pobudziło do ruchu, wprawia w ruch coś innego, a to znowu coś innego, tysiące i tysiące rzeczy zostają w ten sposób wprawione w ruch, to czy pierwszą sprawczą przyczyną ruchu ich wszystkich nie będzie to, co samo sobie daje pchnięcie i samo w sobie wywołuje zmianę? $?^{30}$.

Niewątpliwie udanym zabiegiem Pseudo-Dionizego było przystosowanie teorii neoplatońskich do wymogów chrześcijańskiej nauki. Artysta oddany zarówno służbie muzyki, jak i wszelkiej sztuki powiązanej ze sprawowaniem liturgii nie był pierwotnym inicjatorem swych dzieł. Mimo to nie musiał czuć się ograniczony w swojej wyobraźni - był bowiem ogniwem tego samego łańcucha, o którym pisze Proklos ${ }^{31}$, a którego miejsce w szeregu wyznacza miara jego indywidualnej pobożności.

Dorobek myśli Pseudo-Dionizego wydaje się mieć wartość ponadczasową, trudno bowiem i dziś wskazać (w sensie ogólnym) bardziej adekwatne oczekiwania w stosunku do twórców i twórczości dedykowanej Kościołowi. Wolność artysty, dając swobodę w kształtowaniu dzieła, nie przekreśla roli nadrzędnej idei, która w tym kształtowaniu wydaje się zasadnicza. Oczywiście nie sposób poprze-

ne, a wszelka siła może działać, i nie przestaje być siłą nawet, gdy nie działa [...]. Wszelkie działanie polega na przyjmowaniu ruchu albo na wywoływaniu ruchu. Wobec tego nie wszystko, co jest w ruchu, a w każdym razie nie wszystko, co porusza, jest zmienne. Natomiast wszystko, co jest poruszane przez coś innego, a samo niczego nie porusza, jest śmiertelne"; św. Augustyn, O nieśmiertelności duszy, III, 3, [w:] św. Augustyn, Dialogi filozoficzne, Kraków 2001, s. 314.

${ }^{29}$ Proklos, Elementy teologii, 21, dz. cyt., s. 40.

${ }^{30}$ Platon, Prawa, X, tłum. M. Maykowska, Warszawa 1960, s. 187.

31 „Wielość z kolei wznosi się ku jednej wspólnej przyczynie wszystkich bytów należących do tego samego porządku [...]. W każdym więc porządku i łańcuchu wielość poprzedza jedna jednia, dostarczająca tym, które się w niej znajdują, jednej zasady przyporządkowującej je nawzajem do siebie i do całości, stąd jest rzeczą oczywistą, że wśród rzeczy tego samego łańcucha jedna jest przyczyną drugiej. Ale przyczyna tego łańcucha, w swojej jedyności, niezaprzeczalnie poprzedza jego wszystkie składowe i od niej wszystkie one się wywodzą jako należące do tego samego porządku, i to nie jako coś odrębnego, lecz jako składowe tego samego porządku"; Proklos, Elementy teologii, 21, dz. cyt., s. 41. 
stać na samej formacji duchowej (mierny muzyk, choć pobożny, nie stworzy dzieła sztuki), lecz także nie sposób jej pominać, gdy chodzi o dzieło zdolne oddawać i intensyfikować przeżycia religijne.

\section{Streszczenie}

Doświadczenie i ewolucja greckiego ideału piękna w koncepcji Pseudo-Dionizego Areopagity. Artysta jako pokorny hymnograf

Piękno, jako jedno z kluczowych pojęć filozofii klasycznej, przejęte przez chrześcijaństwo, podlegało dalszej ewolucji. W swej hierarchii, jaką kreślił Platon, piękno wznosi się od cielesności poprzez czyny i prawa aż do prawdy, która odsłania piękno samo w sobie - niezmienne i wieczne. Plotyn uzależniał piękno rzeczy od ich udziału w idei będącej prawdziwą jednością. Wyższe rejony piękna postrzegane mogą być jedynie przez duszę. Punktem kulminacyjnym piękna w ujęciu Plotyna jest Arcypiękno i najwyższe Dobro samo w sobie, które dając wszystko, nie bierze i nie ujmuje sobie niczego. Zgodnie z teorią emanacji to piękno przechodzi również na czyny i uprawiane zajęcia, w tym przede wszystkim sztukę, traktowaną jako narzędzie ukazywania idei, odsłaniającą istotę rzeczy. Udział w odwzorowywaniu piękna wiecznego jest możliwy, bo człowiek - artysta - chociaż stworzony ze zmieszanych substancji, posiada odblask wiecznych idei. Plotyn ustalił hierarchię tych, którzy ze względu na swoje predyspozycje, zdolni są odbyć drogę wzwyż i odkryć arcypiękno boskiego Rozumu. Są nimi: muzyk - miłośnik - filozof. Ta trójstopniowa inicjacja została przez Pseudo-Dionizego przekształcona w koncepcję hierarchii niebiańskiej i odpowiadającą jej koncepcję hierarchii kościelnej. Wspólnie tworzą one drogę do poznania boskich Prawd. Najwyższe substancje odbierają naukę o cudach bożych drogą iluminacji i dalej przekazują ją w dół, niższym hierarchiom, by i one mogły otwierać się na wysławianie i przyjęcie Boga, stosownie do swoich predyspozycji. W ten sposób, stwierdza Pseudo-Dionizy, teksty Pisma przekazały ludziom hymny śpiewane przez Anioły najwyższej hierarchii, w których ukazana została cała wielkość ich niezwykłej światłości. Hymny i kantyki śpiewane przez Kościół są więc odbiciem hymnów pochodzących z hierarchii niebiańskiej. Według Pseudo-Dionizego każdy byt, ponieważ pochodzi od Boga, partycypuje w pięknie, dlatego może stać się źródłem najpiękniejszych kontemplacji. Koncepcja Plotyna zakłada przełamywanie barier w dążeniu do ujrzenia piękna, odpowiednie poprowadzenie muzyka i miłośnika, aby mogli oni ujrzeć prawdziwe piękno. U Dionizego muzyk jest odbiorcą i przekazicielem piękna zawartego w wiecznych, niebiańskich hymnach. Jego wiara sprawia, że staje się bożym narzędziem, pokornym hymnografem. 


\section{Summary}

Experience and evolution of the Cireek ideal of beauty in the concept of Pseudo-Dionysius the Areopagite. Musician as a humble hymnist

Beauty, as one of the key concepts of classical philosophy and affirmed by Christianity, is subject to further evolution. In its hierarchy, as Plato stressed, it rises from the physicality through actions and laws up to the truth that reveals beauty in and of itself - unchanging and eternal. Plotinus believed in the beauty of things from their presence in the ideal, which is true Oneness. Higher areas of beauty can be seen only by the soul. The culmination of Beauty as recognized Plotinus is the highest Beauty and the supreme Good in itself that gives everything and loses nothing. According to the theory of emanation, beauty also passes into deeds and cultivated activities, especially art, which as a tool portrays and reveals the essence of things. Participation in giving form to eternal beauty is possible because a man, an artist, has a vision of eternal ideas. Plotinus established a hierarchy of those, who because of their predispositions are able to advance and discover the beauty of the divine mind: musician - aficionado - philosopher. This three-stage initiation was transformed by Pseudo-Dionysius into the concept of the celestial hierarchy and the Church hierarchy. Together, they form the way to know God's Truths. Highest beings receive the doctrine of God's miracles by means of illumination. Next, they pass it down to the lower hierarchies so that they can glorify and receive God according to their predispositions. In this way, says Dionysius, the texts of the Bible provide the people with hymns, sung by the angels of the highest hierarchy in which was revealed the greatness of their extraordinary light. Hymns and canticles which are sung by the Church are a reflection of the spiritual hymns from the celestial hierarchy. According to Dionysius, any other being participates in beauty because it comes from God, and therefore it can become a source of the most profound contemplation. The concept of Plotinus implies breaking down barriers in the quest to catch a glimpse of beauty, suitable to lead both the musician, the artist, and the lover, so that they can see the true beauty. For Dionysius, the musician is a recipient and utterer of the beauty which is contained in the eternal, heavenly hymns. His faith makes him a tool of God, and he becomes a humble hymnist.

\section{Stowa kluczowe}

imienne: Platon, Plotyn, Pseudo-Dionizy Areopagita

rzeczowe: Piękno, Dobro, Prawda, filozofia, chrześcijaństwo, sztuka, muzyka, idea

\section{Keywords}

names: Plato, Plotinus, Pseudo-Dionysius the Areopagite

things: Beauty, Goodness, Truth, philosophy, Christianity, art, music, idea 


\section{Bibliografia}

Arystoteles, Etyka nikomachejska, tłum. D. Gromska, Warszawa 1956.

Atanazy Wielki, Przeciw poganom, tł. wstęp i oprac. M. Wojciechowski, Warszawa 2000

(Pisma Starochrześcijańskich Pisarzy, 62).

Augustyn, św., O nieśmiertelności duszy, [w:] św. Augustyn, Dialogi filozoficzne, Kraków 2001.

Bazyli Wielki, Homilia na Hexaemeron, [w:] Antologia literatury patrystycznej, t. 2, thum. M. Michalski, Warszawa 1975.

Dokumenty Soborów Powszechnych, t. 1, opr. ks. A. Baron, ks. H. Pietras, Kraków 2007.

Drączkowski F., Patrologia, Pelplin-Lublin 1999.

Gadamer H. G., Prawda i metoda. Zarys hermeneutyki filozoficznej, tłum. B. Baran, Kraków 1993.

Platon, Fajdros, tłum. W. Witwicki, Kęty 2002.

Platon, Fedon, tłum. W. Witwicki, Kęty 1999.

Platon, Prawa, tłum. M. Maykowska, Warszawa 1960.

Platon, Timajos, tłum. W. Witwicki, Kęty 2002.

Platon, Uczta, tłum. W. Witwicki, Kęty 2002.

Plotyn, Enneady I, V, przeł. A. Krokiewicz, Warszawa 2000.

Proklos, Elementy teologii, tłum. R. Sawa, Warszawa 2002.

Pseudo-Dionizy Areopagita, Hierarchia Kościelna, [w:] Pseudo-Dionizy Areopagita, Pisma teologiczne II, tłum. M. Dzielska, Kraków 1999.

Pseudo-Dionizy Areopagita, Hierarchia Niebiańska, [w:] Pseudo-Dionizy Areopagita, Pisma teologiczne II, tłum. M. Dzielska, Kraków 1999.

Pseudo-Dionizy Areopagita, Imiona Boskie, [w:] Pseudo-Dionizy Areopagita, Pisma teologiczne, tłum. M. Dzielska, Kraków 2005.

Pseudo-Dionizy Areopagita, Pisma teologiczne. Imiona boskie. Listy, tłum. M. Dzielska, Kraków 1997.

Stróżewski W., Wokót piękna, Kraków 2002.

Tatarkiewicz W., Historia estetyki, t. 2, Warszawa 2009.

Tomasz, św., Suma teologiczna, tłum. o. P. Bełch, Londyn 1960. 